\title{
REPORT ON ADULT EDUCATORS' COMPETENCE TRAINING FOR THE DEVELOPMENT OF IMMIGRANT AND ASYLUM SEEKER DIGITAL ENTREPRENEURSHIP (EDUAIM)
}

During the 2018-2020 period Klaipeda University (Lithuania), the University of Latvia, the Centre for Education and Innovation Research (Latvia), the University of Tartu (Estonia) and the Folkuniversitetet Kristianstad adult education organisation (Sweden) implemented adult educators' competence training for the development of immigrant and asylum seeker digital entrepreneurship, funded by the Nordplus Adult programme.

Digital entrepreneurship presents an opportunity to promote the successful integration of immigrants and asylum seekers in the labour market (Melnikova et al. 2019: 409). Our approach departed from the "mild digital entrepreneurship" notion proposed by Hull et al. 2007, according to which the digital economy serves as an enhancement of the traditional economy (Melnikova et al. 2019: 410). Therefore, the goal of our project was to develop and validate a competence development program for adult educators who work with immigrants, refugees and asylum seekers. The focus of the program was to develop entrepreneurship and digital entrepreneurship skills.

The idea of the project was developed by one of the coordinators (Klaipeda University) on the basis of an analysis of relevant materials published on the EPALE platform (Melnikova 2018). The project aimed to create a university-led network of adult education institutions that would pilot new methods. These methods, which combine new digital technologies and entrepreneurship education in cooperation with IT entrepreneurs, would develop, in cooperation with the partner universities, a methodology through which to develop and monitor entrepreneurship competence and forms of enterprise education (i.e. social entrepreneurship, creative enterprises). The aim of this would be to develop a methodology of pedagogical use of new digital technologies as an integral part of the adult education curriculum, and to exchange best practices for the development of entrepreneurship as transverse competences at different education levels.

The participating Nordplus countries are very interested in effective ways of integrating immigrants and asylum seekers into the labour market. As the development of ICT prompts new methods of business development (one of which is digital entrepreneurship), education programmes for the target groups should fill gaps in knowledge and skill. However, at present there are no such programmes for immigrants and asylum seekers in the partner countries. Our programme was designed to train adult educators to work with immigrants and asylum seekers and develop their competence in the field of digital entrepreneurship. Trained adult educators then start implementing innovative programmes for the target groups that reflect the needs of the labour market.

\footnotetext{
* This review was supported by the Adult Educator Competence Training for Development of Immigrants and Asylum Seekers' Digital Entrepreneurship project, financed by the Nordplus Adult Programme (NPAD-2018/I 0080).
} 
We organised project workshops in different participating countries. At these workshops, we discussed work in progress, planned further steps in the collaborative endeavour and became more acquainted with each other, thus starting to understand each group's specific competencies and the way in which we could implement and enhance our strengths in cooperation. Partner competencies were rather diverse and complementary. Our Swedish associates have rich experience of adult education practice, including educating immigrants, the Estonian team provided added value to the project through skills in cross-cultural applied anthropological analysis, and the Lithuanian and Latvian teams contributed in the areas of education studies and entrepreneurship research.

Our workshops were not just roundtable discussions between project partners. During our second meeting, held in the autumn of 2018 in Tartu, we joined a class training in adult education at the University of Tartu Centre for Arts. The class was about digital design and the teacher arranged a joint discussion with adult learners who had joined the program with our project participants. The topic was a particular strategy for designing a business web page (how to use dominant visual images, how to functionally structure the information). The fourth project workshop was arranged in Klaipeda in the autumn of 2019 with a project conference that ended with a session at which local immigrant entrepreneurs shared their experiences of developing businesses in an unfamiliar cultural environment. This approach was in line with understanding specific connections between learning and practice: "For entrepreneurial development programmes to be effective, learning must be based in real work situations so that managers can better implement what they have learnt" (Henry et al. 2005).
We anticipate that the project results will raise awareness of Baltic countries' adult education organisations and stakeholders in the field of immigrant and asylum seeker integration. First, we further expect that our countries will improve the quality of their adult education programmes, develop innovative programmes (as in digital entrepreneurship), contribute to promoting collaboration between adult education and the business sector, and adjust adult education to the socio-economic needs of this context. Second, we consider, that the project will contribute to an improvement in the learning process for adults. The project will promote new teaching-learning models, new didactic approaches to competence development and attract more adult learners from different target groups. The competence approach and new methods of competence development will help students and graduates to start their own business and, thus, the project's aim was to enhance graduate employability. Third, we implemented the vision of adult education institutions as service-provider institutions in close cooperation with the local business community. Therefore, we developed administrative and education staff competences in working with the community by involving them in mutually beneficial projects. Fourth, we sought to make an impact on various groups of adult education stakeholders (adult educators, adult learners, researchers, vocational educators, labour market representatives, policymakers, etc.) and people related to education, increasing their ability to take advantage of new opportunities. Fifth, we promoted intercultural 
dialogue and understanding among partner countries, stimulated collaboration and synergy, and encouraged a complex approach to solving similar problems with a special emphasis on quality, but not on comparison.

Julija Melnikova (Klaipeda University) Virginija Jurgaityte (Klaipeda University) Jeḷena Zaščerinska (University of Latvia,

Centre for Education and Innovation Research)

Ludmila Aleksejeva (University of Latvia, Centre for Education and Innovation Research) Art Leete (University of Tartu) Helleka Koppel (University of Tartu) Ingmarie Rohdin (Folkuniversitetet Kristianstad)

Asa Hedlin Olsson (Folkuniversitetet Kristianstad)

\section{References}

Henry, Colette; Frances Hill and Claire Leitch. 2005. Entrepreneurship Education and Training: Can Entrepreneurship Be Taught? Part I. - Education and Training 47 (2): 98-111. DOI: https://doi.org/10.1108/00400910510586524.

Hull, Clyde Eiríkur; Yu-Ting Caisy Hung, Neil Hair, Victor Perotti and Richard DeMartino. 2007. Taking Advantage of Digital Opportunities: A Typology of Digital Entrepreneurship. - International Journal of Networking and Virtual Organisations 4 (3): 290-303. DOI: https://doi.org/10.1504/IJNVO.2007.015166.

Melnikova, Julija. 2018. Adult Educators' Competence Training for Development of Immigrants and Asylum Seekers' Digital Entrepreneurship: Theoretical Framework. - EPALE. https://epale.ec.europa.eu/sites/default/ files/epale_digital_entrepreneurship.pdf (accessed October 22, 2020).

Melnikova, Julija; Virginija Jurgaityte, Jel̦ena Zaščerinska, Ludmila Aleksejeva, Art Leete, Helleka Koppel, Ingmarie Rohdin and Asa Hedlin Olsson. 2019. Immigrants and Asylum Seekers' Digital Entrepreneurship Competence: Evaluation of the Theoretical Framework. - Conference Proceedings 5: 9th Balkan Region Conference on Engineering and Business Education (BRCEBE) \& 12th International Conference on Engineering and Business Education (ICEBE) "Unique Opportunity to Share, Learn and Network", Sibiu, România 16-19 October 2019, edited by Claudiu Vasile Kifor, Norbert Grünwald and Lucian Lobonţ. Sibiu: Lucian Blaga University of Sibiu, 408-416. 